\title{
Integrating Decentralized Rainwater Management in Urban Planning and Design: Flood Resilient and Sustainable Water Management Using the Example of Coastal Cities in The Netherlands and Taiwan
}

\author{
Thorsten Schuetze $^{1, *}$ and Lorenzo Chelleri ${ }^{2}$ \\ 1 Department of Architecture, Sungkyunkwan University, Suwon 440-746, Korea \\ 2 Department of Geography, Autonomous University of Barcelona, Barcelona, Spain; \\ E-Mail: lorenzo.chelleri@uab.es \\ * Author to whom correspondence should be addressed; E-Mail: t.schuetze@skku.edu; \\ Tel.: +82-31-299-4763; Fax: +82-31-290-7570.
}

Received: 25 February 2013; in revised form: 19 April 2013 / Accepted: 29 April 2013 / Published: 10 May 2013

\begin{abstract}
Urbanized delta areas worldwide share a growing tendency of exposure to water stress induced by the effects of climate change and anthropogenic factors, threatening the operation of infrastructure systems and future urban development. The important synergistic impacts coexisting with freshwater scarcity are increasing urbanization rates, subsiding soils, saltwater intrusion in aquifers and rivers, coastal erosion, and increased flooding. Innovative design strategies and concepts for the integration of decentralized rainwater management measures can contribute to the integrated and climate resilient planning of urban spaces that are threatened by climate change scenarios that worsen the security of urban infrastructures and the future availability of fresh water. Decentralized rainwater management, including retention, storage, and reuse strategies that are integrated into spatial planning and urban design, can reduce flood risks while simultaneously enhancing freshwater availability. This paper discusses a paradigm shift in urban water management, from centralized to decentralized management (that is, from threats to opportunities), using the example of two case studies. Concepts and strategies for building climate resilient cities, which address flood control, the protection of freshwater resources, and the harmonization of a natural and more sustainable water balance, are presented for Almere (Rhine Schelde Delta, The Netherlands) and Hsingchu (Dotzpu Delta, Taiwan).
\end{abstract}


Keywords: climate change; flooding; freshwater scarcity; decentralized rainwater management; climate resilience; urban development; Almere; Hsingchu

\section{Introduction}

Low elevation coastal delta zones account for only $2 \%$ of the world's land surface area, but nearly $13 \%$ of the world's urban population lives in these zones [1]. The effects of climate change pose increasing stress on delta areas [2], since the synergistic impacts of sea level rise (SLR), saltwater intrusions, flooding, and increasing soil-erosion patterns contribute to the vulnerability of generally densely populated areas, often associated with large growing cities [3,4]. The most serious impacts, which paradoxically can both be expected at the same time, are increasing flooding events [5] and decreasing freshwater availability [6]. By the year 2000, 150 million people worldwide were living in cities with perennial fresh water shortages and approximately 886 million urban dwellers were affected by seasonal water shortages [6]. According to modeling results from WaterGap (in [7]) the population living in river basins facing severe water stress is expected to rise until 2050 at least to 3.6 billion people (according to the "sustainability first" scenario), or even up to 5.1 people (according to the "security first" scenario).

The challenges related to climate change adaptation in the most vulnerable coastal areas worldwide have been addressed in various studies such as those by Sharma et al. [8] and Fuchs et al. [9], from essential general aspects related to scales and institutions [10], to the specific measures needed to build resilience to specific vulnerabilities [11]. However, the main challenges are the protection of coastal cities from unexpected yet increasing climate-driven impacts and from freshwater scarcity. The latter is often human induced, and can be foreseen, planned for, and alleviated through landscape management and a more efficient use of precious freshwater resources [6]. Indeed, freshwater availability can be enhanced by measures that can at the same time decrease the risks and impacts of flooding. Within the concept of integrated water resources management, the application of such systemic and sustainability orientated thinking poses serious challenges [12], but decentralized harvesting, management, and utilization of both rainwater and stormwater is a win-win strategy for the re-equilibration of the water cycle in urban settlements, balancing climatic and anthropogenic water-related pressures [13,14].

This paper focuses on delta cities, since they are hot spots where pressures induced by both climate change (such as sea level rise, increasing storm events, changes in temperatures, and precipitation patterns) and anthropogenic influences $[15,16]$ pose the most serious challenges for water resource management. These challenges call for a paradigm shift in the current centralized water management practices. While centralized infrastructure systems for water management have well-known advantages, they also have various disadvantages that are mainly based on an expensive and inflexible long-term building strategy. Centralized systems are not resilient in cases of damage because their structure is a chain of linked and interdependent parts. They are not adaptable to changes in climate and demography (not without considerable effort) and the related changes in volumes of water demand 
and discharge (demand), nor to changes in the mechanism for water depuration and reuse (for example the division of mixed sewage into different streams of grey and black water).

In contrast to centralized and non-flexible infrastructure systems, decentralized water management facilitates relatively easy adaptation to the effects of changes in demography, climate, and technological development, and facilitates the collection, storage, and reuse of potential resource flows. Therefore, decentralized water management measures emerge as management, planning, and design tools that promote a more sustainable and climate resilient use of water fluxes [17-20].

The general hypothesis behind sound environmental practices for decentralized water resource management is to convert threats into opportunities, and waste into resources. Climate-related water stresses could be avoided by decentralizing their potential impacts, such as by decentralizing rainwater and stormwater retention and storage. At the same time, fresh water can be provided to urban areas by the same source, from decentralized stored rainwater and stormwater. New and innovative rainwater management and integrated planning (combining the management of resources and water), seems indeed to be crucial for introducing a new water paradigm that relies on urban climate resilience and sustainability. According to the authors' findings, strategies for decentralized rainwater management offer very promising approaches to cope with the potential problems of traditionally centralized water management. An example of the main disadvantages of centralized sewage systems is the collection and discharge of stormwater in centralized drainage systems, often together with other highly polluted sewage flows. Such mixed sewer systems are not yet sustainable and are generally not well integrated in the spatial design of the urban environment.

Depending on the different basic conditions of a specific location, appropriate solutions for decentralized, sustainable, and resilient rainwater management systems can differ significantly. Therefore, ad hoc strategies and design concepts need to be developed that are adapted to the specific local basic conditions and which follow specific local needs. The discussion of different strategies and findings that are based on research and design projects aims to raise awareness amongst engineers, urban planners, designers, and decision makers about the possibilities and advantages of the integrated urban and landscape design of climate resilient cities by means of sustainable rainwater management systems.

\section{Approach and Methods}

This paper discusses innovative sustainability strategies and design concepts for the integration of decentralized rainwater strategies in the planning and water management practices of international delta cities. These strategies and concepts mostly involve landscape architecture, urban design, and planning and have been developed in the framework of both academic research and urban design projects.

The foundation for the research and design projects presented in this paper was the qualitative (and as much as possible quantitative) analysis of the landscape conditions (such as the natural, cultural, and manmade landscape structures). The past and present local and territorial planning instruments and perspectives for future development were also analyzed. Finally, a set of practically proven approaches, tools (such as nature-orientated and environmentally sound technologies and systems), and methods for sustainable rainwater harvesting, management and utilization were applied in the spatial planning and urban design process of climate resilient and sustainable future urban development scenarios. 
Challenges and opportunities regarding the adaptation of the urban environment to the present and expected effects of climate change were considered and finally two concrete case studies were chosen in order to represent the general framework of challenges related to flooding and rainwater management for delta cities.

The case of Almere in The Netherlands represents all the potential problems related to a city located below sea level and in a lowland delta area of a moderate European climate. Situated within the Dutch polder landscape, Almere offers useful insights from the new urban development concept of a "self sufficient water polder". The development of strategies to cope with the effects of climate change is essential for areas in The Netherlands, particularly for those areas situated below sea level. It is imperative to implement measures for more sustainable water management due to the environmental and climatic drivers threatening the urban systems. From September 1998, the occurrence of a relatively regular rainfall of approximately $130 \mathrm{~mm}$ in $24 \mathrm{~h}$ caused severe flooding in many areas of the Dutch lowlands [20] because the standard drainage capacity of Dutch polder landscapes is calculated to remove only $14 \mathrm{~mm}$ rainfall per $24 \mathrm{~h}$. Consequently, a new concept for the climate adaptive water management at a regional level in Dutch polders was developed, based on the introduction of a basic guiding model for more self-sufficient water systems. The aim of the so-called "strategy for sustainable water management in the 21 st century" is to reduce, to the greatest possible degree, both the discharge of (comparably clean) rain- and stormwater from polders, as well as the inlet of (comparably polluted) river or canal water in polders. Such measures contribute significantly to the adaptation of the negative water-related effects caused by climate change, which include flooding, freshwater scarcity, and declining freshwater quality in the polders' water systems [14,21].

The guiding model for self-sufficient water systems follows the concept of decentralized rainwater management harvesting and utilization, particularly in new urban developments [22]. The model is based on a three-step strategy, developed in 2001 by the Dutch advisory committee on water management in the 21 st century [23]. The key strategy and aim is to solve water management problems in a decentralized way, at the source of origin, and to avoid shifting problems to other areas. The first step of high priority is the decentralized retention and collection of rainwater (for example retention by means of green roofs or collection from building and traffic areas). The second step, of equal priority, is the local storage of collected rainwater such as in ditches, ponds, lakes and tanks. According to the third step, of equal priority, only surplus water, which can neither be retained nor stored, may be discharged from polders to rivers or canals, and finally to the sea. The two main aims of the three-step strategy are to avoid flooding by decentralizing the rainwater retention and collection in designated areas, in the case of heavy precipitation events with peaks in stormwater runoff, and at the same time to cope with water shortages during periods of drought by the seasonal storage of decentralized collected rainwater.

The described strategy for decentralized and self-sufficient rainwater management is in fact a key component of the climate resilient development strategy in The Netherlands. Accordingly, in new urban developments in the Dutch lowlands the integration of open surface water bodies is compulsory and required by district water boards. Generally, a specific portion (e.g., 5\% or 10\%) of the land surface area of new urban developments must consist of open water bodies [24]. In the "City of the Sun" located in the municipality of Heerhugowaard, in the province North Holland, even $25 \%$ of the city area consists of water [25]. This guiding model introduces self-sufficiency (concerning freshwater and 
rainwater management responsibility) as a key strategy for building sustainable and flood resilient urban environments in lowland deltas. The general model is introduced, and specific insights, planning schemes, and exemplary design features are presented.

For the case of Hsingchu (Taiwan), this study proposes solutions for water-related challenges which are principally similar to the Almere case, but within the context of hilly territories located above sea level and a tropical Asian climate. In the Asian case study, another recurrent situation is tackled, in which decentralized rainwater management strategies can help in coping with water-related urban problems and challenges, particularly seasonal flooding and drought. In Asia, coastal cities usually face extreme and frequent stormwater runoff problems, particularly during the monsoon seasons, causing downstream flooding and upstream erosion patterns in the river basins. At the same time, urban developments, with their high freshwater demand, put pressure on the locally available renewable freshwater resources. The Hsingchu case study exemplifies such water-related problems. Depending on the season, the city is forced to cope with either drought or extreme rainfall and flooding, while it is affected at the same time by freshwater shortage and water must be imported from other territories. The region of Hsingchu is an example of an area that has been affected by expanding urbanization processes and related environmental degradation over the last few decades. The population of Hsingchu is growing faster than other urban centers in Taiwan. At the same time, the water consumption per capita is increasing. The sealing of natural ground and loss of green areas due to urbanization processes contributes to both increased stormwater runoff intensity and flooding frequency.

The strategy, analytical methods, and materials used in the Hsingchu case are similar to those used in the Almere case. Various aspects are discussed in this study, including the general proposed model, the introduction of the hybrid floodplains concept, regional and specific planning, and the design concepts for rainwater retention, management, storage, and utilization. From this discussion, the study will propose a method for building a flood resilient and sustainable water management system in Hsingchu city which will serve as a model for the integration of decentralized rainwater management systems in the planning and design of sustainable and climate resilient urban territories with comparable basic conditions.

The intermediate and final results of the research, as well as the design processes for both case studies, were evaluated using qualitative sustainability criteria while regarding the contribution of such criteria to the spatial quality of the urban environment. The economic feasibility of the integrated approach discussed in this study is based on research and pilot project findings and evaluations $[14,25,26]$ and on the realistic assumption that the investment and management costs can be shared with other sectors such as landscape and recreation. Furthermore, costs related to the construction and management of conventional climate resilient urban infrastructure systems can be reduced. However, an analysis of the costs and benefits is beyond the scope of this paper.

\section{Case Studies Presentation}

The first step for addressing integrated sustainable water management strategies in urban spatial planning and design is the assessment of the relevant basic conditions of the concerned areas. These include information about the total area, local landscape, land use, the number of inhabitants, water demand, climatic data (such as precipitation availability and variability), geology, the availability of 
spaces for decentralized water management, etc. Accordingly, in the subsequent subsections such relevant data is presented for the case studies in The Netherlands and in Taiwan, prior to Section 4, which discusses the development scenarios for decentralized rainwater management in urban planning and design.

\subsection{East Almere, The Netherlands}

The city of Almere is located around $70 \mathrm{~km}$ east of Amsterdam (52 $\left.22^{\prime} \mathrm{N} 5^{\circ} 13^{\prime} \mathrm{E}\right)$ in the Flevoland polder area, which was reclaimed from the Ijsselmeer in the 1950s and 1960s. East Almere, the object of this case study, is a newly planned city expansion of Almere (see Figure 1). Currently, only 1\% of the farmland, which covers the area on which the new urban development of East Almere is planned to be built, consists of open water [27].

Figure 1. Location of East Almere in The Netherlands.

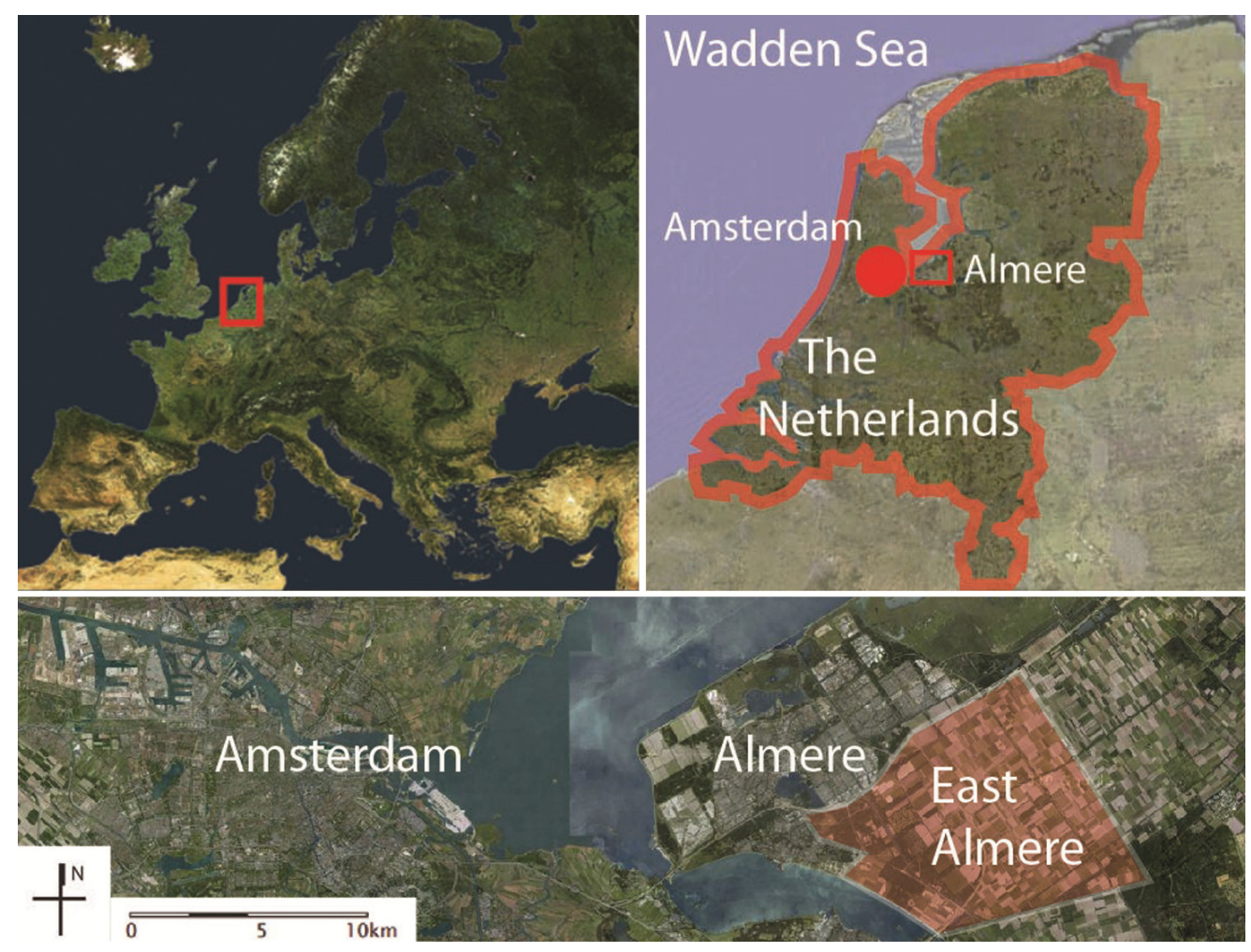

The height of the current land surface area of the polder is between $-3 \mathrm{~m}$ and $-5 \mathrm{~m}$ below sea level. Four pumping stations maintain the groundwater in the project area at a constant level of $1.2 \mathrm{~m}$ below the surface area. The maximum daily pumping capacity facilitates the removal of approximately 11 to $18 \mathrm{~mm}$ water from the Flevoland polder and the project area.

The soil consists of sea clay with different characteristics. The upper layer with a depth of $30 \mathrm{~cm}$ is ploughed, followed by a layer of matured cracked water permeable silt with a soil porosity of $20 \%$ [28] and depth of $90 \mathrm{~cm}$. Below a depth of $1.2 \mathrm{~m}$, the soil consists of non-matured silt with a low water permeability of 10 to $100 \mathrm{~m}$ per day [29]. The total thickness of the silt layer in the project area varies mainly between $4 \mathrm{~m}$ and more than $8 \mathrm{~m}$. 
The climate is moderate with an average precipitation per year of $754 \mathrm{~mm}$, while the average potential evaporation is $562.9 \mathrm{~mm}$ per year [30]. According to the average Dutch climate, the rainfall exceeds the potential evaporation during the winter months, which results in freshwater surplus (wet period). During the summer months, the potential evaporation exceeds the rainfall, which results in freshwater demand (dry period). Figure 2 presents the average monthly precipitation and evaporation rates for Almere [30], as well as the balance of evaporation and precipitation in mm over the period of one year.

Figure 2. Average monthly precipitation and evaporation rates (left) and balance of evaporation and precipitation (right) for Almere.
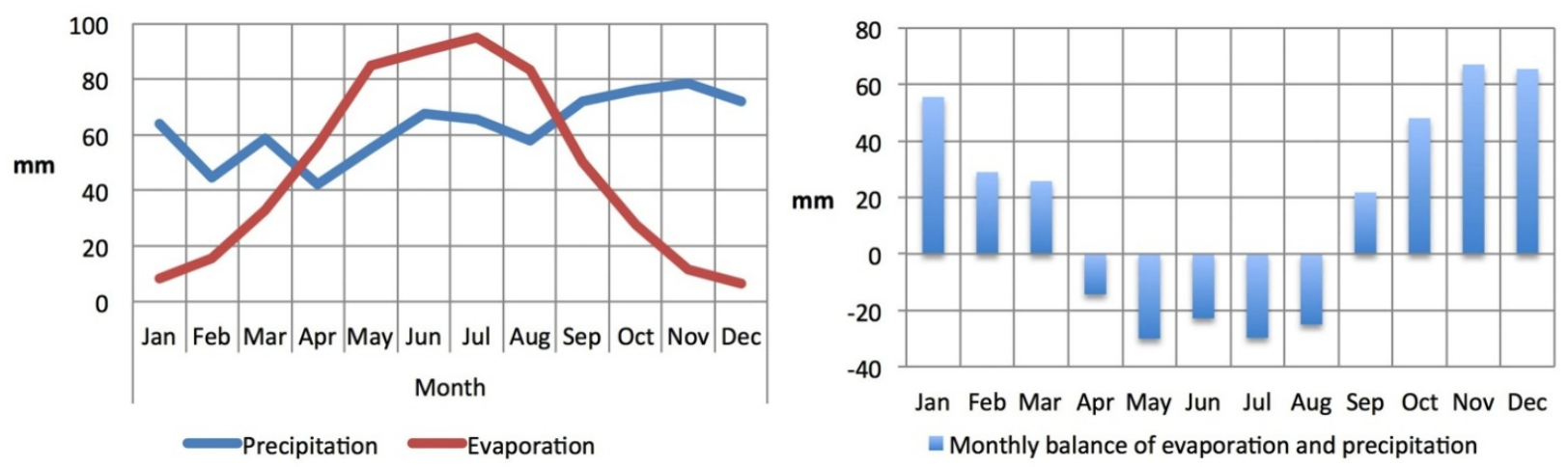

The case study development scenario for East Almere, discussed in the framework of this paper, consists of a total area of approximately 7000 ha. It is expected that 40,000 people will live in 16,000 dwellings. The drinking water demand is estimated to be $97 \mathrm{~L}$ per person per day. The total drinking water demand is accordingly $1,414,740 \mathrm{~m}^{3}$ per year. This amount is similar to a level of $20 \mathrm{~mm}$ of water per year if evenly spread over the entire project area.

The water balance for the case study scenario in East Almere is based on average yearly precipitation and evaporation rates which have been estimated based on climate change development scenarios by 2050 for the investigated area and the estimated land use [27]. In addition, the drinking water demand is included. Table 1 illustrates the quantification of the water balance converted in $\mathrm{mm}$ per year for a dry, an average, and a wet year.

Table 1. Water balance per dry, average, and wet year for the project area in East Almere converted into $\mathrm{mm}$.

\begin{tabular}{|c|c|c|c|c|c|c|}
\hline \multirow{2}{*}{$\begin{array}{l}\text { Sources of Water } \\
\text { Inlet, Discharge } \\
\text { \& Water Balance }\end{array}$} & \multicolumn{2}{|c|}{ Dry Year } & \multicolumn{2}{|c|}{ Average Year } & \multicolumn{2}{|c|}{ Wet Year } \\
\hline & $\begin{array}{l}\text { Inlet } \\
(\mathbf{m m})\end{array}$ & $\begin{array}{c}\text { Discharge } \\
\text { (mm) }\end{array}$ & $\begin{array}{l}\text { Inlet } \\
(\mathrm{mm})\end{array}$ & $\begin{array}{c}\text { Discharge } \\
\text { (mm) }\end{array}$ & $\begin{array}{l}\text { Inlet } \\
(\mathrm{mm})\end{array}$ & $\begin{array}{c}\text { Discharge } \\
\text { (mm) }\end{array}$ \\
\hline Precipitation & 410 & & 800 & & 1150 & \\
\hline Drinking Water & & 20 & & 20 & & 20 \\
\hline Evaporation & & 650 & & 530 & & 360 \\
\hline Water Balance & & -260 & & -250 & & 770 \\
\hline
\end{tabular}

The retention and seasonal storage of all available rainfall in the project area would facilitate the avoidance of flooding and the use of regionally available and renewable freshwater resources during 
dry seasons. According to the results of the discussed research, on average, the total annual rainfall in the territory exceeds the total yearly freshwater demand, including the demand for drinking water supply. The water balance is only negative in dry years.

The introduction of more polder-independent water management systems that aim to cope with regional water-related problems is the basis for the development of a new form of urban planning and development in coastal low lands, calling for a self-sufficient, decentralized, and integrated management of water [14], as discussed in Section 4.

\subsection{Hsingchu, Taiwan}

The coastal city of Hsingchu in Taiwan is located approximately $100 \mathrm{~km}$ south of the capital of Taipei $\left(24^{\circ} 49^{\prime} \mathrm{N} 120^{\circ} 59^{\prime} \mathrm{E}\right)$. The lowest part of the hilly territory is located approximately $34 \mathrm{~m}$ above sea level. Figure 3 illustrates the location of Hsingchu, showing population growth, total water consumption, lost green areas, and flooding frequency in comparison with the metropolitan region of Taipei. The majority of urbanized land is located in the drainage zones of the natural river, Dotzpu. The city is affected by both seasonal flooding risks and water shortages due to its high freshwater demand and periodically limited freshwater availability. Water consumption must be temporarily rationed during periods of drought. The freshwater demand of the Hsingchu metropolitan region is supplied by large-scale surface water reservoirs (dams) which are located upstream of the river Dotzpu. Rainwater is generally drained as fast as possible from urban and agricultural areas (to be discharged into the river Dotzpu and finally into the sea) to avoid flooding and related damage to urban infrastructures. The flooding-related problems are severe due to the specific climate and hilly geomorphology [31].

Figure 3. Location of Hsingchu in Taiwan.
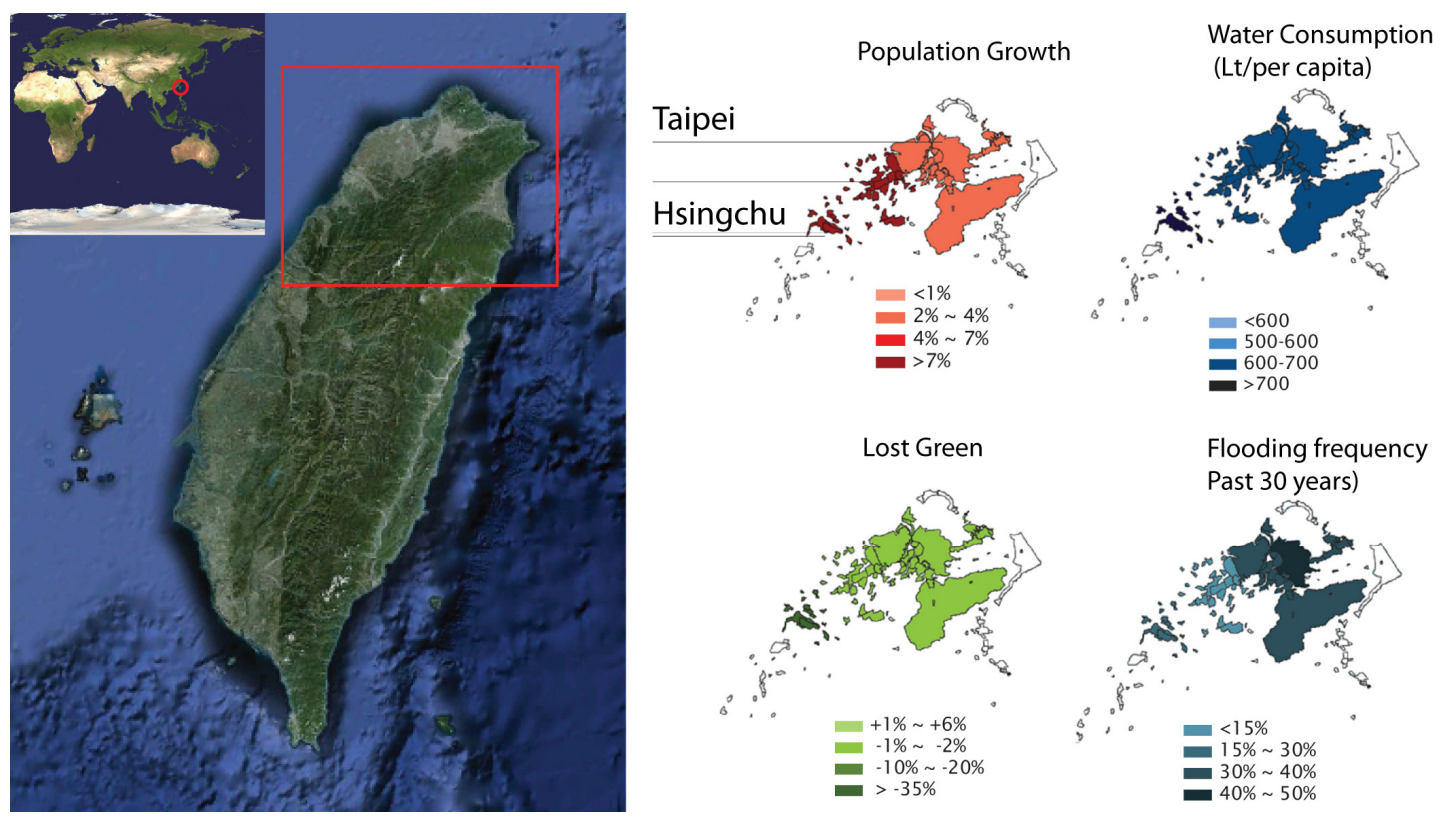

The groundwater level in Hsingchu is on average between 0.1 and $30 \mathrm{~m}$ under the land surface area, depending on the season and the elevation of the land surface above the river basins. Areas located close to rivers have a quite shallow groundwater table while the freeboard is growing with higher 
elevation. However, the groundwater tables vary depending on the season and rainfall and the specific location. In the case study situated in the Dotzpu River area, the groundwater level in the hilly territories is at an average between 9.4 and $14 \mathrm{~m}$ under the land surface area. In areas situated close to river beds, the groundwater level can vary between 0.1 and $6 \mathrm{~m}$ under the surface area in wet seasons and between 0.6 and $8.8 \mathrm{~m}$ in dry seasons.

The groundwater districts are composed of Pleistocene and Holocene aquifers that are only recharged by local precipitation. Under natural conditions, at least $55 \%$ of the total yearly groundwater is recharged by precipitation during the months from May to September. Holocene aquifers comprise coarse alluvial deposits with a hydraulic conductivity of $10^{-2}$ to $10^{-3} \mathrm{~cm} / \mathrm{s}$. Pleistocene aquifers consist of semi-consolidated conglomerate, lithic graywacke, subgraywacke, and shale. The hydraulic conductivity is in the range of $10^{-4}$ to $10^{-5} \mathrm{~cm} / \mathrm{s}$ [32].

The climate is tropical with an average rainfall of $1845 \mathrm{~mm}$ per year and an average potential evaporation of $1389 \mathrm{~mm}$ per year. According to the average climate in Hsingchu, the rainfall exceeds the potential evaporation from February to August (wet period), which results in freshwater surplus. The potential evaporation exceeds the rainfall from September to January, which results in freshwater demand (dry period). Figure 4 presents the average monthly precipitation and evaporation rates for Hsingchu [31] as well as the balance of evaporation and precipitation in mm over the period of one year.

Figure 4. Average monthly precipitation and evaporation rates (left) and balance of evaporation and precipitation (right) for Hsingchu.
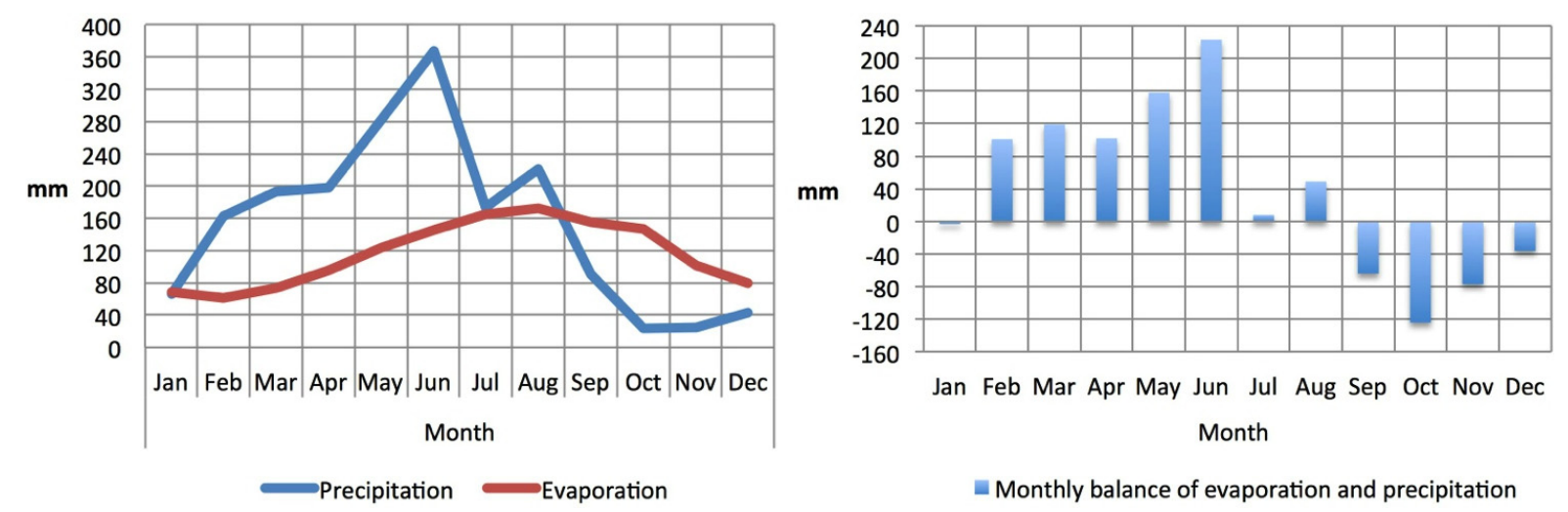

The New Development zone of Puyu is a district of Hsingchu, which needs to be newly developed and is the case study development scenario discussed in this paper (see Figure 5). Puyu has a total area of 378 ha and its expected population is 40,000 . The domestic drinking water demand is estimated to be $224 \mathrm{~L}$ per person per day [33]. The total drinking water demand is accordingly $30,270,400 \mathrm{~m}^{3}$ per year. This amount equates to a level of $865 \mathrm{~mm}$ of water per year if evenly spread over the entire project area.

The water balance for the case study scenario in the New Development Area of Puyu is based on average yearly precipitation and evaporation rates based on the estimated land use. In addition, the domestic drinking water demand is included. The quantification of the water balance converted in $\mathrm{mm}$ per year is illustrated in Table 2.

Similar to the Almere case study, the retention and seasonal storage of all available rainfall in the project area would facilitate flood avoidance and the use of regionally available and renewable 
freshwater resources during dry seasons. According to the results of the discussed research, on average, the total annual rainfall in the territory equals approximately the yearly freshwater demand, including the demand for drinking water supply.

Figure 5. Map of Hsingchu metropolitan region, showing the case study area in which The New Development zone, Puyu, is located.

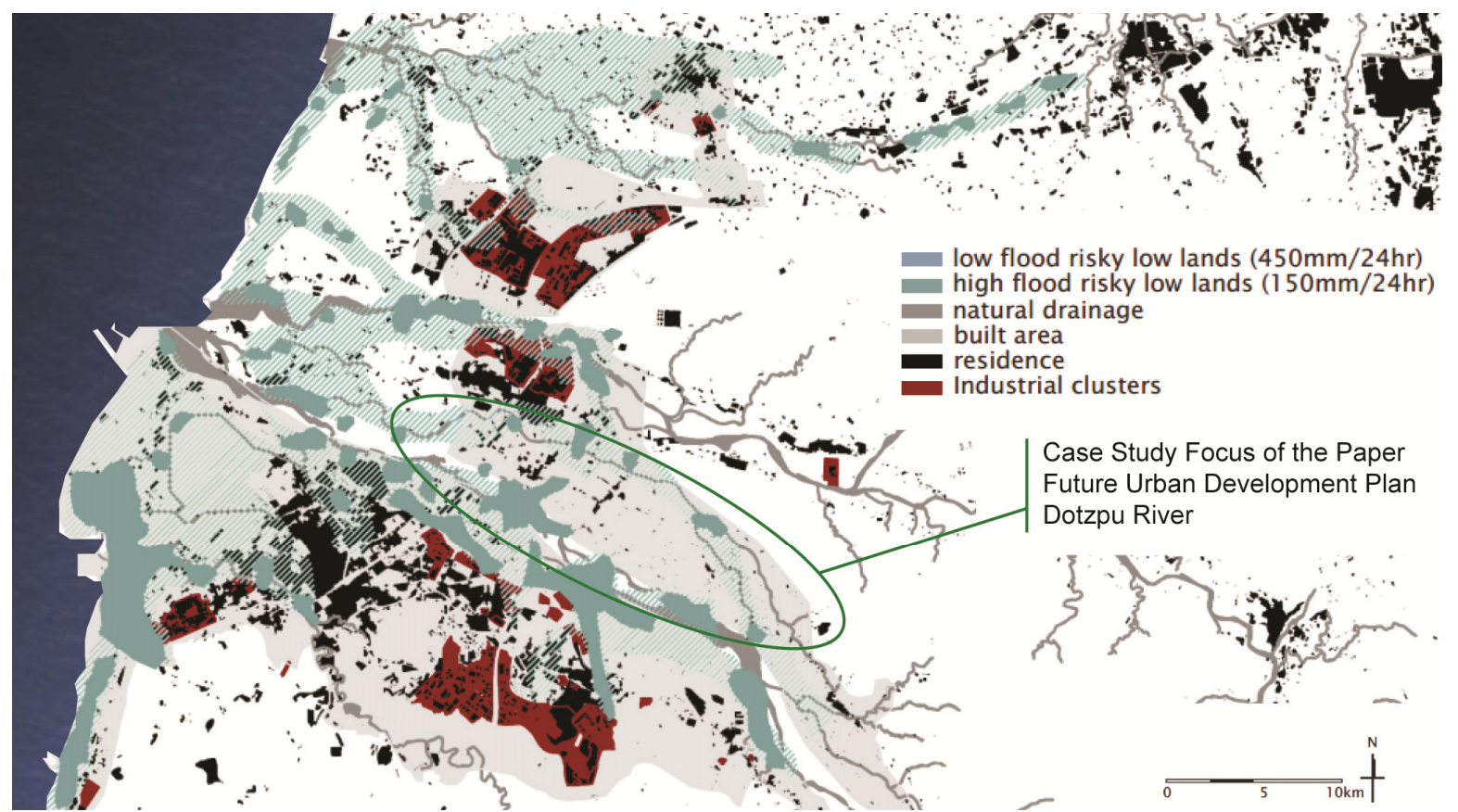

Table 2. Water balance per average year for the project area in Puyu converted into mm.

\begin{tabular}{|c|c|c|}
\hline \multirow{2}{*}{$\begin{array}{l}\text { Sources of Water } \\
\text { Inlet, Discharge } \\
\text { \& Water Balance }\end{array}$} & \multicolumn{2}{|c|}{ Average Year } \\
\hline & $\begin{array}{l}\text { Inlet } \\
(\mathrm{mm})\end{array}$ & $\begin{array}{c}\text { Discharge } \\
(\mathrm{mm})\end{array}$ \\
\hline Precipitation & 1845 & \\
\hline Drinking Water & & 865 \\
\hline Evaporation & & 972.3 \\
\hline Water Balance & & \\
\hline
\end{tabular}

\section{Proposals and Discussion}

According to the data discussed in the case study presentations, a shift towards more integrated and sustainable water management is suggested, which takes advantage of excessive rainwater availability during wet seasons. Stormwater runoff could be collected and stored during wet seasons to be used during dry seasons. In this way, seasonal freshwater availability could be balanced with the total yearly freshwater demand. The retention of seasonally available rainwater would facilitate runoff control and flood avoidance. The harvesting and utilization of the annual rainfall in the case study areas could contribute significantly to the supply of the urban freshwater demand and facilitate a sustainable freshwater autonomy.

The separation of rainwater from other sewage streams at the source is the indispensible basic condition for the implementation of urban design strategies for decentralized rainwater harvesting and 
management in general, and therefore also in the cases of the examples discussed in this paper. Urban design and development strategies for decentralized rainwater management are discussed in the following section.

\subsection{Flood Control and Freshwater Augmentation by Rainwater Management in East Almere, The Netherlands}

To realistically achieve the sustainable development of East Almere, existing planning paradigms need to be extended and shifted to more integrated approaches. The findings of the research discussed in this section clearly underline the need to move towards a transition in the usual polder's configuration and in its (centralized) water management [27].

Based on the concept of a self-sufficient polder water management system, the following aims and criteria for the future sustainable and climate resilient development of East Almere have been previously addressed in the integrated process for the design and planning of a future development scenario as follows [27]:

- Preparation and adaption to future effects of climate change.

- Avoidance of soil subsidence.

- Minimization of external water dependency.

- Retention and storage within the city area of as much rainwater as possible.

- Protection of water quality.

- Purification (desirably through natural sound processes) and the use of local freshwater resources.

- Minimization of technical and invisible technical water infrastructure such as pipelines and pumps, and utilization of local topography for the management of water flows.

- Integration of visible water in urban design, according to the vision of "The Netherlands live with water" program (with which The Netherlands wishes to experiment with a paradigm shift from defending cities from water, to accepting and managing water as a positive driver in landscape functioning).

In order to include all of the above-listed criteria within the scenario for the future development of East Almere, the design of the urban area and the water system is based on two main strategic measures for the decentralization of rainwater and stormwater management: (i) the extensive use of invisible groundwater bodies; and (ii) visible open surface water bodies and wetlands for the nature-orientated purification of stormwater and storage of rainwater. Wetlands are connected within a citywide water system which connects different freshwater storage areas in order to create synergies by water circulation, to enhance the water quality as well as the re-distribution of accumulated water. The system is explained briefly in the next section. The design of the existing drainage system of Almere facilitates the discharge of a maximum of $1.5 \mathrm{~L}$ of water per second per hectare out of the polder. In the future, water management systems similar to the current system, which consist of drainage canals and pumps, will be retained to facilitate the discharge of water from the polder in cases of emergency such as extreme rainfall over long periods [27].

A large part of the rainfall occurring in the area of East Almere could be infiltrated and stored underground in the form of groundwater to cope with rainwater peaks and to reduce stormwater runoff. 
A $30-\mathrm{cm}$ to $120-\mathrm{cm}$ layer under the surface area consisting of matured silt could be used for the storage of groundwater. The storage capacity is calculated based on the existing soil porosity of approximately $20 \%$, from 30 to $120 \mathrm{~cm}$ in depth below the grass roots. The introduction of a dynamic groundwater level, with fluctuations of $60 \mathrm{~cm}$ between a maximum level of $60 \mathrm{~cm}$ and a minimum level of $120 \mathrm{~cm}$ below the grass roots, would facilitate the seasonal storage of up to $120 \mathrm{~mm}$ rainfall (or $120 \mathrm{~L} / \mathrm{m}^{2}$ ) on site. A permanent maximum groundwater level of $60 \mathrm{~cm}$ below the grass roots would facilitate the storage of peak precipitation events of $60 \mathrm{~mm}$ in the remaining $30 \mathrm{~cm}$ of matured silt. Due to the decentralized nature of the rainwater infiltration, the rainwater retention rate can be adjusted to natural pre-urban conditions, establishing a new sustainable natural equilibrium while attempting to balance the amount of sealed surface due to urbanization processes. However, groundwater fluctuation and land uses need to be adjusted according to each other because natural, agricultural, and urban areas have different requirements regarding groundwater levels. Therefore, it is difficult to introduce fluctuating groundwater levels in large and continuous areas. In cases which require the realization of large rainwater storage capacities, but where the capacity of groundwater storage is limited, alternative additional measures are required in order to facilitate effective rainwater retention and to cope with rainwater peaks. Such measures include the installation of extensive green roofs on buildings and the creation of rainwater-retention basins near urbanized areas with sealed surfaces [27].

For a self-sustaining water system in East Almere, a portion of $20 \%$ of the total development area, planned partly outside the built up area, must be reserved for open water bodies and wetlands (to obtain a closed autonomous water system, including biological purification and fluctuating water levels). Therefore, two open water bodies have been introduced within the planning and design process of the new urban development of East Almere, one for the seasonal rainwater storage and the other for the buffer storage of peak precipitation events (see Figure 6). The seasonal storage can be filled during wet periods, and serve as a fresh water reservoir for dry periods. At the same time, the peak storage can receive and manage rainfall during heavy precipitation events. For instance, during the summer months, both peak precipitation events and droughts can occur. For this reason, a circulation system has been introduced, connecting the two storage areas (since both can be required during the summer months). Such a circulation system can also contribute to the purification of water by nature-orientated systems, for example by means of constructed wetland areas along the planned canals.

To minimize the energy required for the operation of the water system, its effective design takes advantage of the height differences in land topography and water levels. The seasonal storage is located on higher ground and the peak storage is located in the low-lying area. After precipitation events, rainwater accumulates in the peak storage basin by gravity flow. Above a certain minimum water level in the peak storage, the surplus of relatively clean freshwater is pumped to the seasonal storage. This has two purposes: firstly, the water level in the peak storage is lowered, to provide enough peak storage capacity for future precipitation events. Secondly, water from the peak storage can be easily distributed by gravity flow and reused when needed, e.g., during dry periods during the summer. The portion of the peak and seasonal storage basins constitute a portion of $7.1 \%$ and $2.7 \%$, respectively, of the total urban development area of East Almere. The relative calculated maximum fluctuation between maximum and minimum water levels is about $31 \mathrm{~cm}$ for the peak storage and $553 \mathrm{~cm}$ for the seasonal storage. A large part of the required energy for pumping can principally be regained by using the pressure of the seasonal water to run a turbine and a generator when the water is 
distributed by gravity flow to the lower urban areas. In that case, the seasonal water storage system can function as a "battery" for both collected freshwater in the form of rainwater, and electrical energy (see Figure 6) [27].

Figure 6. Site plan of East Almere with proposed land uses and water management scheme.

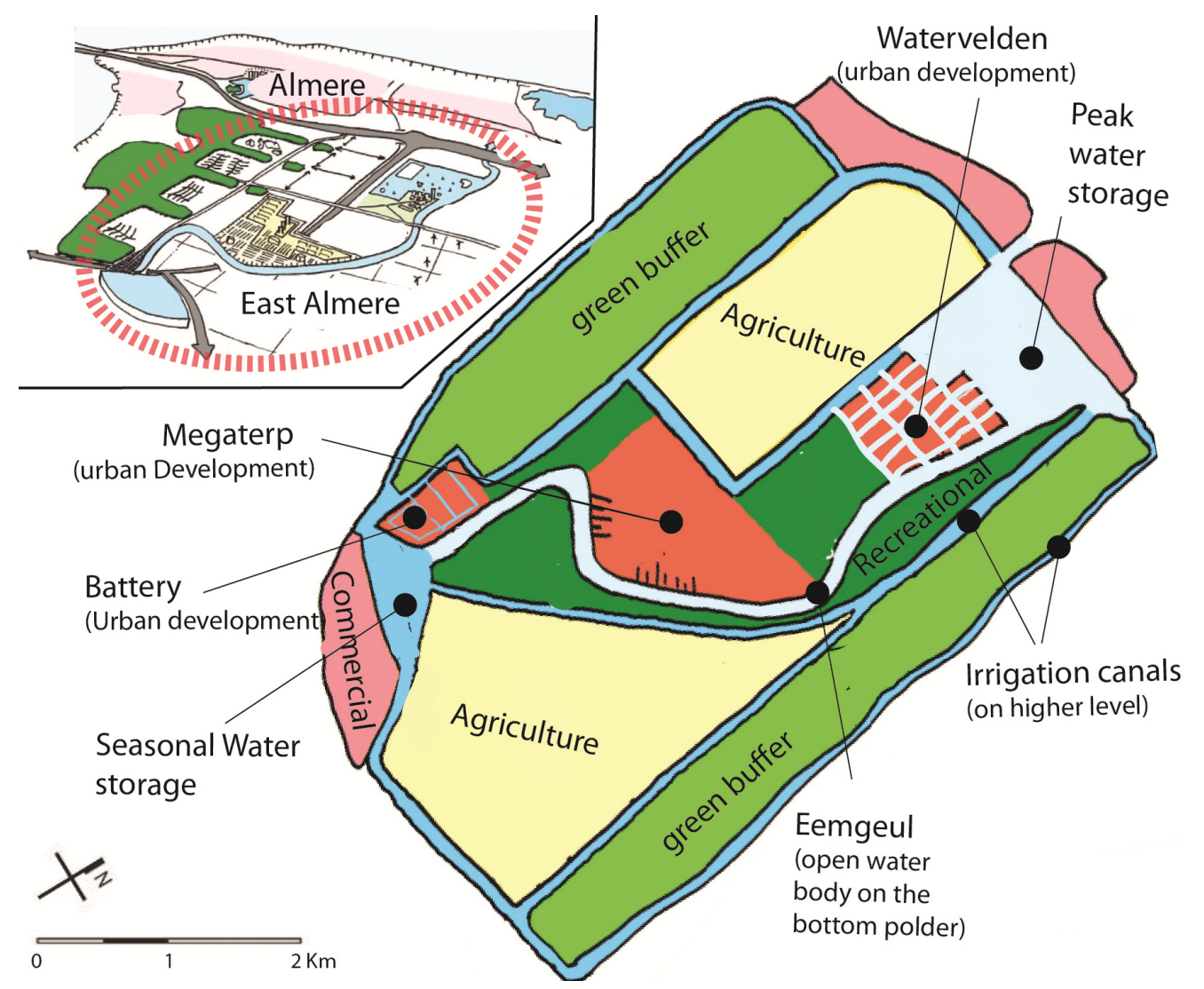

\subsection{Specific Characteristic of Different Districts for Sustainable Urban Water Management}

Three main urbanized areas have been planned for the water self-sufficient polder concept of East Almere. Within the districts, the "water fields" (watervelden), "mega dwelling mount" (terp), and "battery" (batterij) each have their specific functions, characteristics, structure, and design. The city center watervelden is located in the artificial "peak storage" lake, near a canal (Eemgeul), connecting the peak storage water body with the seasonal storage water body. The center consists of elevated building areas that have the character of small islands, surrounded by small streams, connecting the Eemgeul and the lake. This area is located on the lower polder level. Therefore, the green areas, infrastructures, and ground floors of some buildings are designed to be waterproof and to be compatible with a fluctuating water level, according to the function of the peak water storage area. In this way, they can be affected but not damaged by flooding after extreme rainfall, even if the maximum water level of the seasonal storage is exceeded. The remaining buildings are elevated and connected to each other to facilitate access during short flood periods, whereby parts of the city center might be partly affected by high surface water levels. Flood-proof traffic and building areas can be designed either in the form of floating structures or situated on piles (see Figure 7) [27]. 
Figure 7. Bird's eye view (from northeast to southwest) of East Almere city center watervelden. Peak storage fluctuating water level is illustrated for the situation with high water level after heavy rain (bottom left) and the regular situation with low water (bottom right).

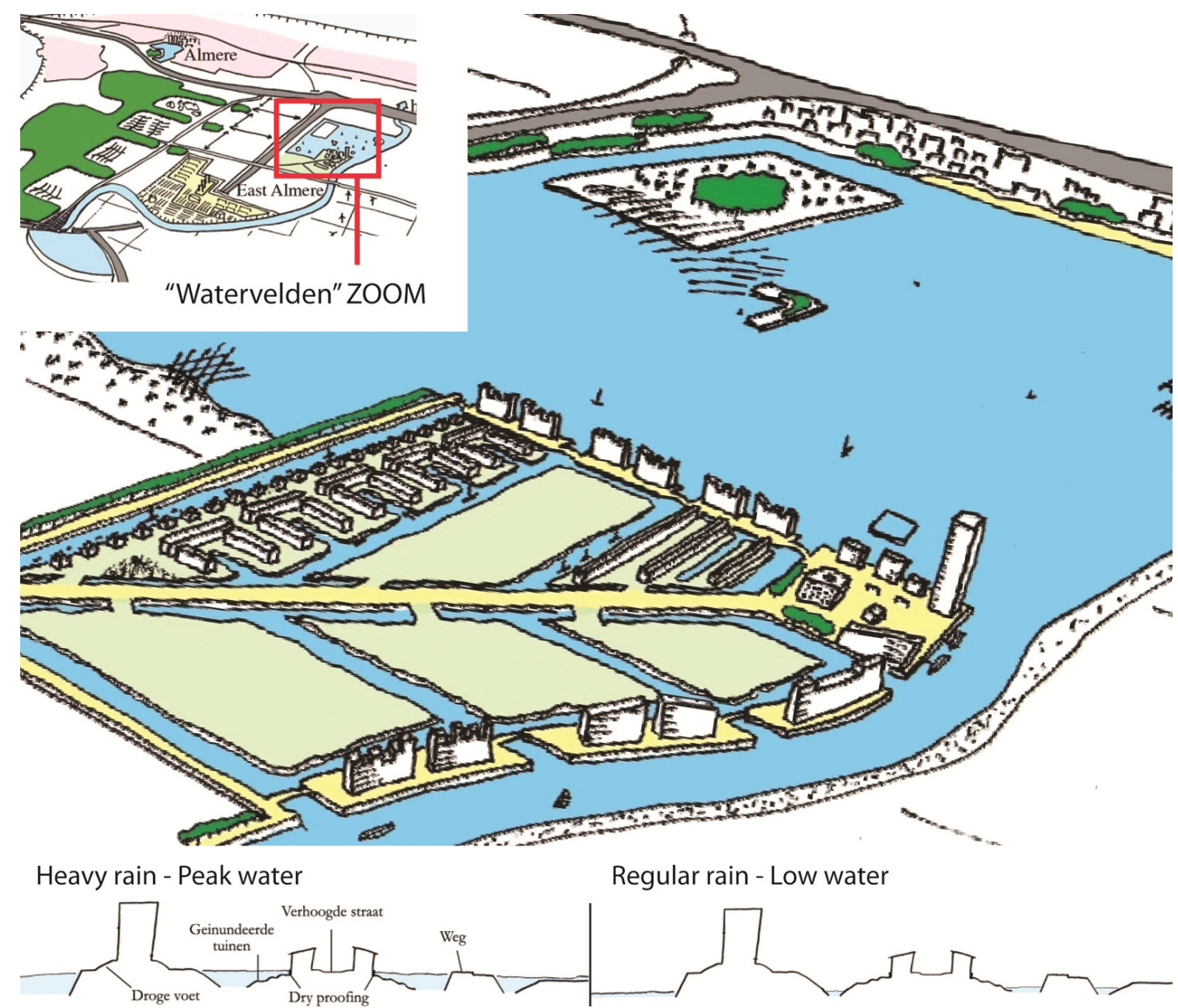

The district "mega dwelling mount" is built elevated on a large dwelling mount made of sand. The area is originally situated in a higher part of the polder, which is sensible for soil subsidence. An artificial heightening of several meters was chosen for this area in order to strengthen the natural characteristics (higher elevated ground) of the area, as well as to create a $100 \%$ flood-proof environment and an appropriate basis for the construction of the city center. The street level of the district is above sea level and buildings therefore cannot be affected by high water levels and flooding. Due to the location of the connecting highways and train tracks on the present land surface area, these infrastructures are planned to be covered with sand and housed in tunnels (see Figure 8) [27].

The building site preparation of weak peat and/or clay soils by adding a layer of 1-2 $\mathrm{m}$ sand is common practice in The Netherlands [34] and has been applied for the construction of Amsterdam [35]. However, buildings need to be erected on piled foundations to avoid settlements. In the case study area, the foundations need to reach the Pleistocene sands, which are located at a depth of between 5 and $11 \mathrm{~m}$ under the current soil surface layer. The main advantages of constructing the city core on a dwelling mount consisting of sand are that the danger of subsiding soil in lowlands can be significantly reduced and the surface area will be above sea level and be completely flood proof. At the same time, 
the mount can function as a flood-safe shelter for people in the case of emergency in the lower lying polder areas. It is advisable to create a high urban density to reduce the individual contributions to the comparable high construction effort for the dwelling mount. Local mining of the required sand can reduce related transport effort. According to the relatively high elevation of the mega dwelling mount district and the good infiltration properties of the ground (sand), it is expected that all rainwater can be infiltrated easily. Also, in the case of extreme precipitation events, it is expected that water surplus will therefore not cause any problems. Moreover, the area might also be sensible for droughts.

Figure 8. Bird's eye view (from northeast to southwest) of East Almere district "mega dwelling mount". Sections illustrate the city core during dry seasons (bottom left) and during wet periods with extreme rainfall (bottom right).

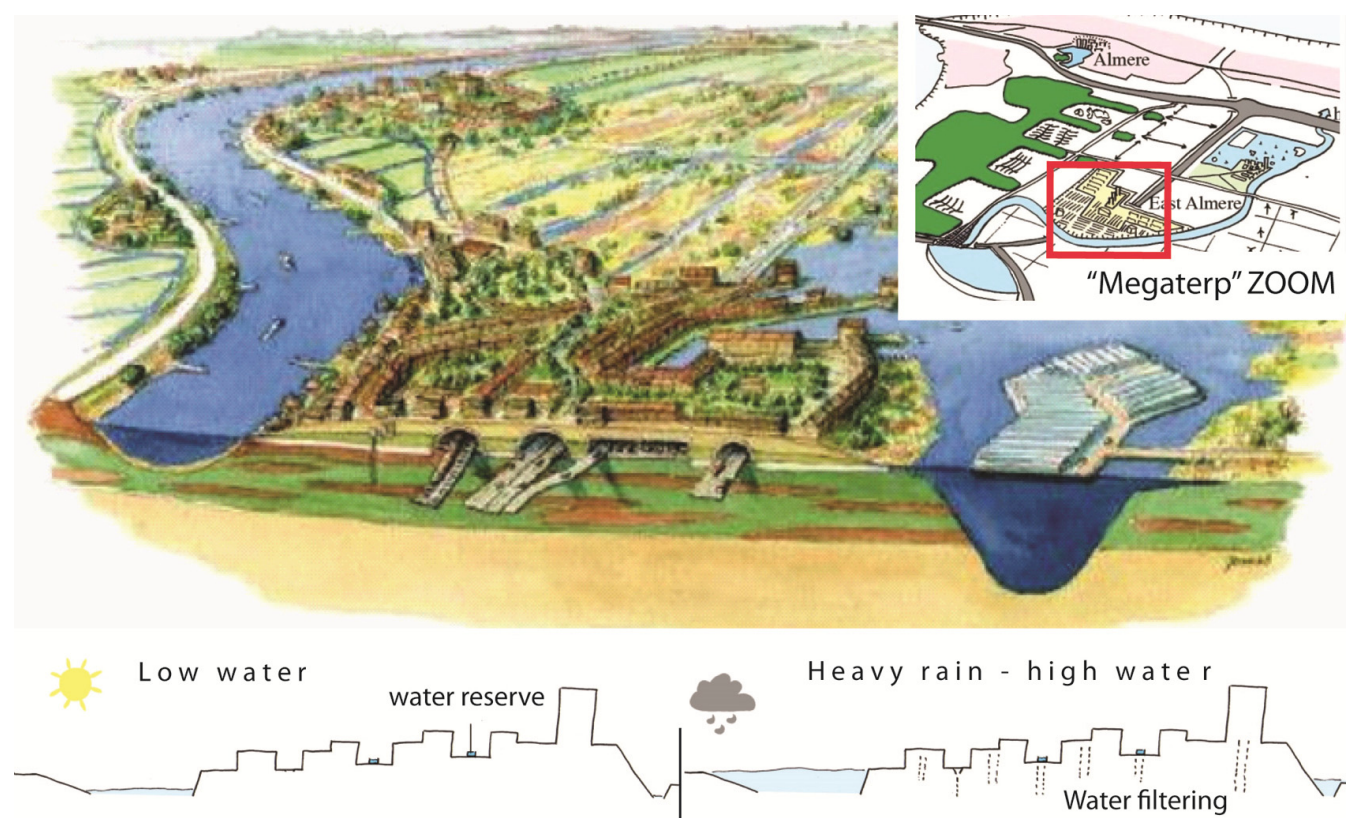

In order to reduce the dependency on irrigation with water stored in the lower polder areas, stormwater can be collected from sealed traffic areas and stored in open wetlands. These could serve multiple purposes: landscaping, ecology, and water supply for irrigation and in cases of emergency (firefighting). In the area itself, the character of visible surface water areas is quite similar during different seasons, while the layout of the lower lying areas is significantly affected by higher or lower water levels (see Figure 8) [27].

The city district "battery" (see Figure 9) is located at the border between the artificial seasonal storage lake and the canal, which leads to the peak storage lake. The selected area is located on land with a naturally relatively high elevation and low soil subsidy properties. Therefore, it is expected that traditional building technologies can be applied to the construction of the district. The structure is designed according to the concepts of traditional Dutch polder cities, that of building blocks on properties that are separated by canals (grachten). Therefore, the area needs to be partly heightened and topped up with sand to create a sufficient freeboard between the canals and the land surface area. The specific characteristic of the district is its situation at the border of two areas with different water levels, with a minimum difference in height of $1.2 \mathrm{~m}$ and a maximum difference of $6.4 \mathrm{~m}$. Therefore, 
the "living with water" concept was taken as a starting point for the urban design. To further reinforce this feature, irrigation (retour) canals are located throughout the district [27].

Figure 9. Bird's eye view (from southwest to northeast) of East Almere district "battery". Sections illustrate the water levels in the "battery" districts' water systems after heavy rain and high water (left) and after regular rain and low water (right).

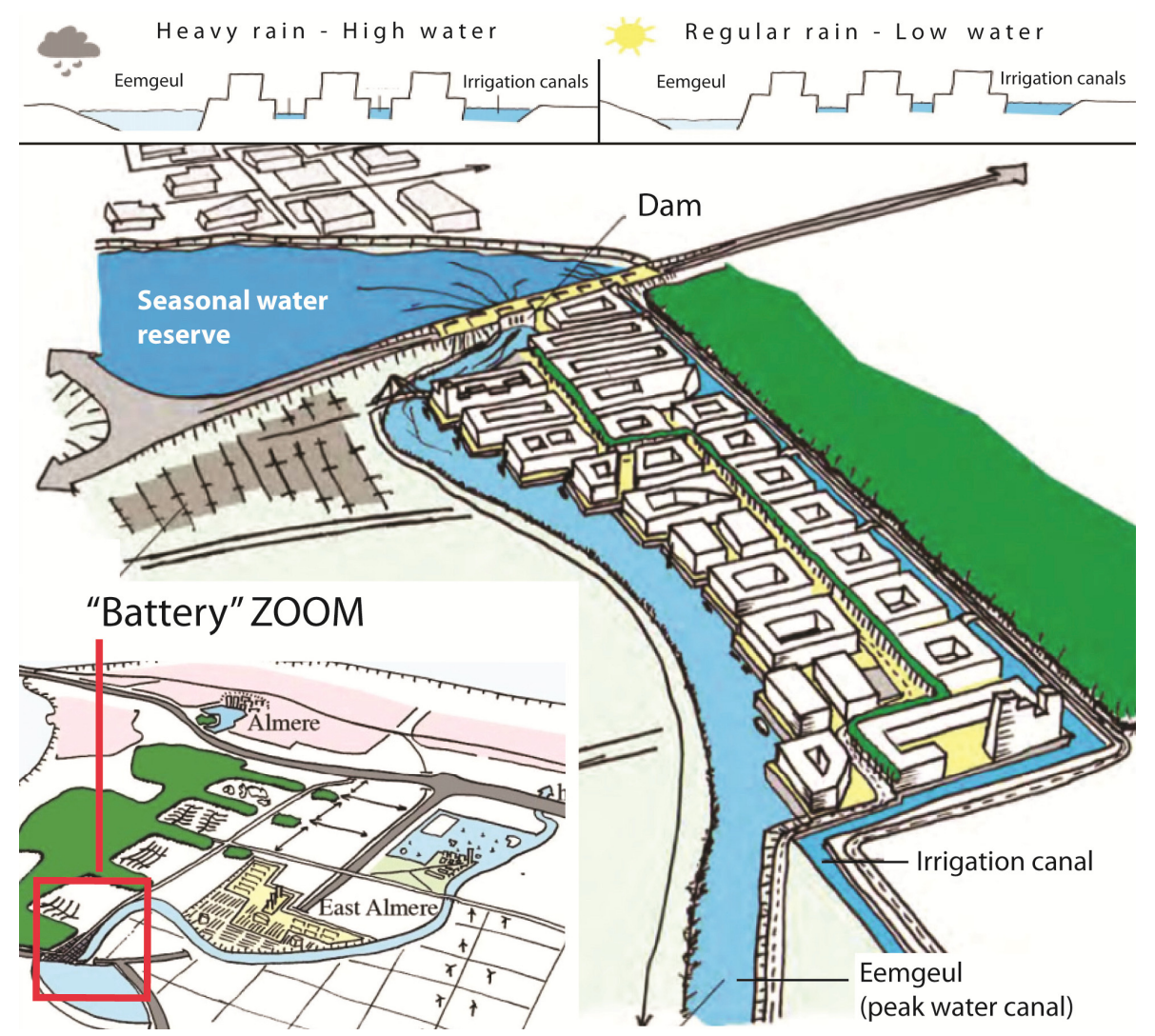

The water stored in the seasonal storage reservoir (located at least $1.2 \mathrm{~m}$ above the maximum water level of the peak storage lake and the canal), contains potential energy. The majority of the water collected in the lower areas of Almere East needs to be transported there by means of pumps, which consume electric energy. The majority of this energy can be gained back by generating energy, using the water pressure when water is released from the seasonal storage lake (the "battery"), to supply the lower lying areas of Almere. This would happen in times of need such as during dry seasons and the vegetation period, when the evapotranspiration exceeds the precipitation, resulting in seasonal drought. The lower lying areas are irrigated from several smaller streams that are designed to meander through the lower lying areas, facilitating irrigation [27].

\subsection{Flood Control and Freshwater Augmentation by Rainwater Management in Hsingchu, Taiwan}

Following the methodology of the case described in the previous sections, this section discusses the results of an exemplary research and design project for integrated urban planning and design that employed decentralized rainwater management measures. Insights from scenario development and research are presented and discussed. The basic concept for the sustainable water management for the visionary case study for Hsingchu entails the integration of a network of both ground and open surface 
water bodies for the retention and storage of rainwater in new urban development areas as well as in existing floodplains and agricultural land. Different floodplains have been designed along the Dotzpu River, which serve as buffers for runoff during high river tides. Areas that serve as floodplains in the case of extreme precipitation events, which occurred in the past only once in 100 years, but which will become more common due to the effects of climate change, are reserved for agricultural purposes and will not be used for built-up areas [31].

According to the specific regional topography, the river basin carries water throughout the year. River basin areas that are affected by flooding are assigned to two zones. Traditionally, flood plains are assigned to areas that will be flooded after $150 \mathrm{~mm}$ of rainfall in $24 \mathrm{~h}$. Extended flood plains are assigned to areas that are affected by flooding after $450 \mathrm{~mm}$ rainfall in $24 \mathrm{~h}$. Agricultural areas that are situated in floodplains next to streams benefit from constant water availability. Extended flood plains located at a distance from streams are designed to only be filled with water during the wet seasons. Their specific appearance and land use differ during the wet and dry seasons. During dry seasons, the land can be used for agricultural or recreational purposes, whereas it can function as a rainwater and stormwater retention and infiltration area during wet seasons. The landscape therefore has the characteristic of an urban "sponge." According to the multiple functions, areas functioning also as extended floodplains can be called "hybrid floodplains," which can create synergies between social, agricultural, rainwater and river water management functions in urban neighborhoods. Figure 10 illustrates the location of the case study area in Hsingchu, the spatial pattern of different flood zones, and the location of hybrid floodplains [31].

The retention of the total rainfall on farmland such as rice paddies can be achieved by small interventions, for instance, by heightening the ridges around the fields from the standard $15 \mathrm{~cm}$, to $35 \mathrm{~cm}$. Similar measures that aim for the retention and infiltration of rainfall at the place of landing have also been realized successfully in other parts of the world, such as in Rajasthan (India), where micro dams (Johads) are constructed for the retention and infiltration of monsoon rain [36]. Another example can be found in the semi-arid rural areas in the northeast of Brazil, where rainwater harvesting and management is successfully practiced for freshwater augmentation and climate change adaptation by the construction of micro dams [37].

According to the proposed function of the landscape, its form is dependent on the specific season and on the occurring rainfall and resulting water fluctuations. During the summer, when typhoons regularly cause extreme rainfall, resulting in severe flooding, all types of hybrid floodplains with different characteristics (which will subsequently be described in more detail), would become wetlands or ponds. The landscape could than have the typology of a seasonal recreational water park, providing different water-related activities for the citizens. During the autumn, with low and irregular rainfall, the floodplains could be kept relatively dry and be used for different recreational purposes. During the comparably dry winter, the floodplains can be used for urban farming, which is profitable for farmers due to agricultural production, and for citizens for recreational and educational pursuits.

The introduction of hybrid floodplains is the most fundamental structural urban design tool and was used before the design, planning, and realization of soft and hard infrastructures for urban developments. In the next section, examples of interventions at the district and neighborhood level will be explored in more detail, using the example of the Puyu district, in order to integrate the regional 
decentralized rainwater management strategy with the guiding principles for the design of urban settlements.

Figure 10. Maps with illustrations of the Dotzbu River, indicating the location of the New Urban Development zone Puyu in Hsingchu, flooding zones for different rainfall scenarios, and hybrid redefined floodplains.

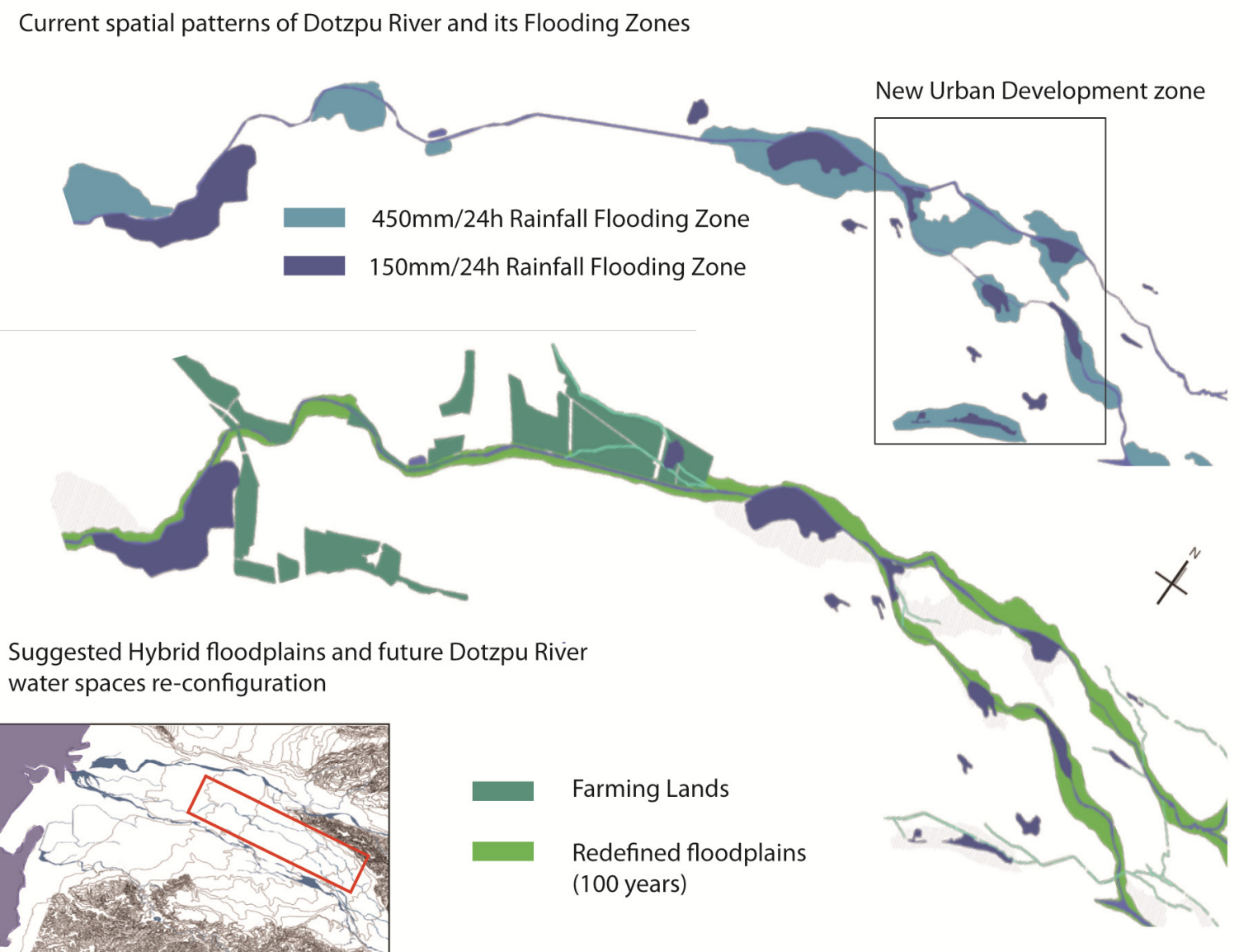

\subsection{Specific Applications and Design Proposals for the Dotzpu River and New Urban}

Development Zone, Puyu

The New Urban Development zone of Puyu is planned along and between the three main natural creeks of the river Dotzpu (Figure 11). The first approach for addressing sustainable water management in the urban design is the reservation of sufficient space for the local retention and slowed drainage of rainwater, stormwater, and river water, by creating a connected network of green areas, small streams, hybrid floodplains, and retention lakes. The second, but equally important measure is the design of a floodplain adjacent to the creeks that can be flooded in the case of the extreme high runoff and river tides that occur once in 100 years. These should have the characteristic of a green zone and should not contain any urban infrastructures or buildings that can be damaged by flooding (see Figure 11).

Once the general strategy is defined and implemented in the draft urban layout, specific landscape and water engineering structures need to be designed in order to manage rainwater flows between the three creeks of the river Dotzpu and to build a decentralized network of retention lakes and streams. 
The design needs to be adjusted to the layout and location of built-up areas (which are located within and between water-retention plains and lakes), in order to manage stormwater flows originating from the built-up areas as close as possible to their origin. This was regarded as the most effective way to address the retention and slow discharge of stormwater in the configuration of waterretention areas by designing a decentralized network of green flood plains connected by small streams that stretch and flow diagonally in the direction of the creeks of the Dotzpu River (Figure 11). In the case of emergency, the network facilitates the discharge of surplus water, which can neither be retained nor infiltrated for groundwater recharge, to the creeks of the Dotzpu River by gravity flow (Figure 11) [31].

Figure 11. Map with proposed layout of the New Urban Development zone Puyu, with the location of specific urban functions, characteristics of different neighborhoods, different floodplains, and water streams.

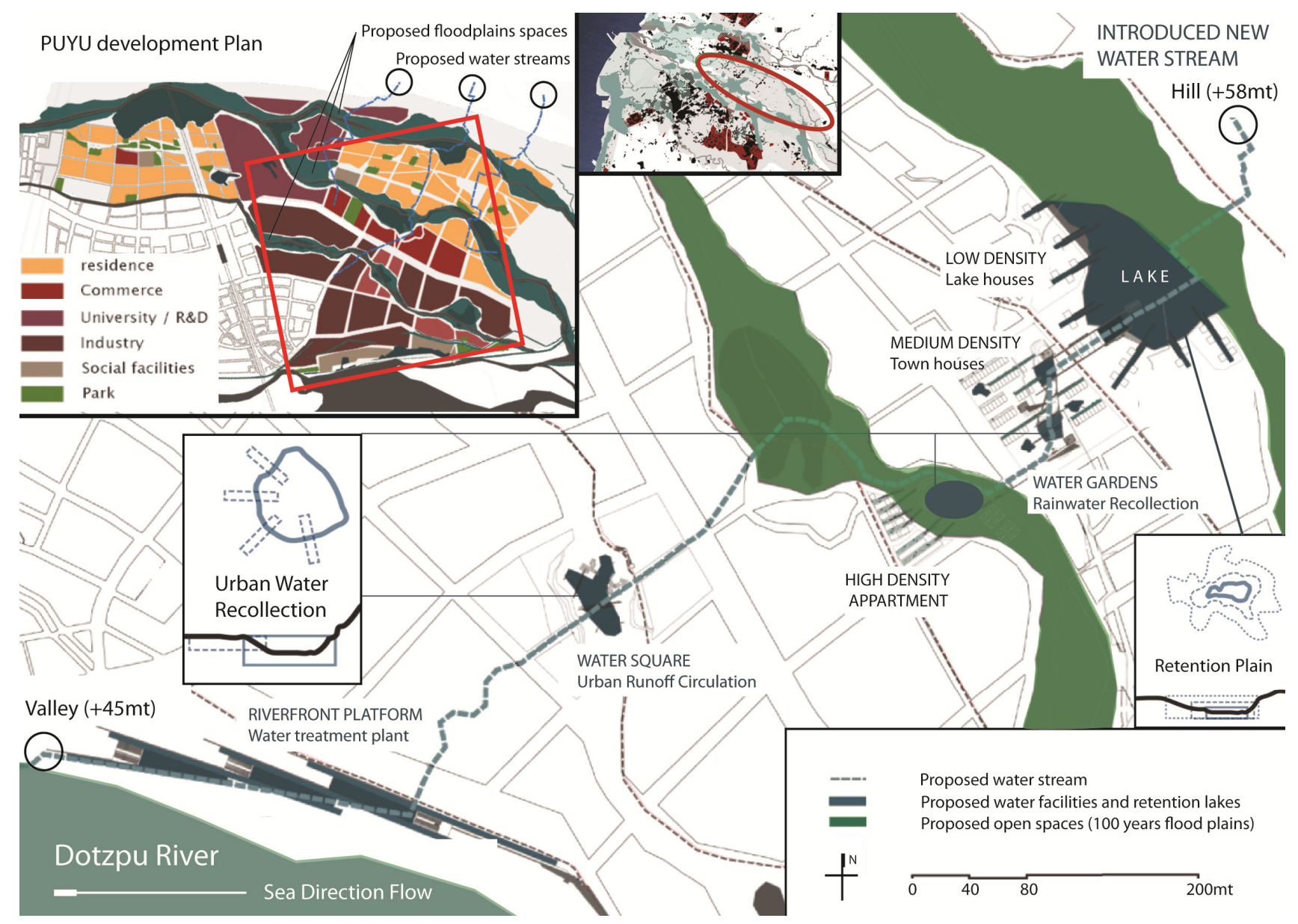

The three creeks of the Dotzpu River are located at different topographical heights (see also Figure 12). The proposed new hybrid floodplains and streams flow from a first floods control zone located upstream, which has the function of keeping stormwater within a retention lake, to a second runoff control zone where rainwater from buildings is collected, stored, and infiltrated in a multifunctional recreational open space. From there, the floodplain zone stretches further downhill, towards an urban water reuse zone, in which both rainwater collected from buildings, and water from the stream, can be used for non-drinking purposes in the direct neighborhood such as the industrial area and the university campus. Finally, the water that reaches downstream is further purified within a natural water treatment 
zone, in which multifunctional open spaces are mixed with nature-orientated means for water purification before the stream reaches the main course of the Dotzpu River and the riverfront, of which the hybrid floodplain areas are designed to also facilitate recreational activities.

The urban and spatial planning of the specific neighborhoods needs to integrate all urban functions within the overall design of the sustainable urban water management system, including decentralized measures at the source. The overall water system is based on the gravity flow of water and the priority of a series of interventions following the logic of sustainable water management. Accordingly, guiding models and specific requirements for the design of the different districts, and their specific role in the overall sustainable water management system, have been formulated. The following different requirements need to be fulfilled in the specific neighborhoods, starting from the peak and following the gravity and priority flow of stormwater runoff. Flexible flood control, rainwater retention, and infiltration are applied to agricultural and natural areas. Runoff collection of rainwater and its retention and infiltration in recreational areas is practiced in new urban developments. The use of collected and purified rainwater accumulated in redeveloped recreational areas can be realized, as much as possible, in existing city districts. Further downstream, nature-orientated water treatment for additional purification of the remaining overflow and runoff should be executed in areas that can also function as hybrid river floodplains for recreational purposes, such as with the character of a public park (see Figure 12).

Figure 12. Cross-section along the proposed new network of hybrid floodplains and artificial streams for retention, infiltration, purification, storage, and slow discharge of rainwater.

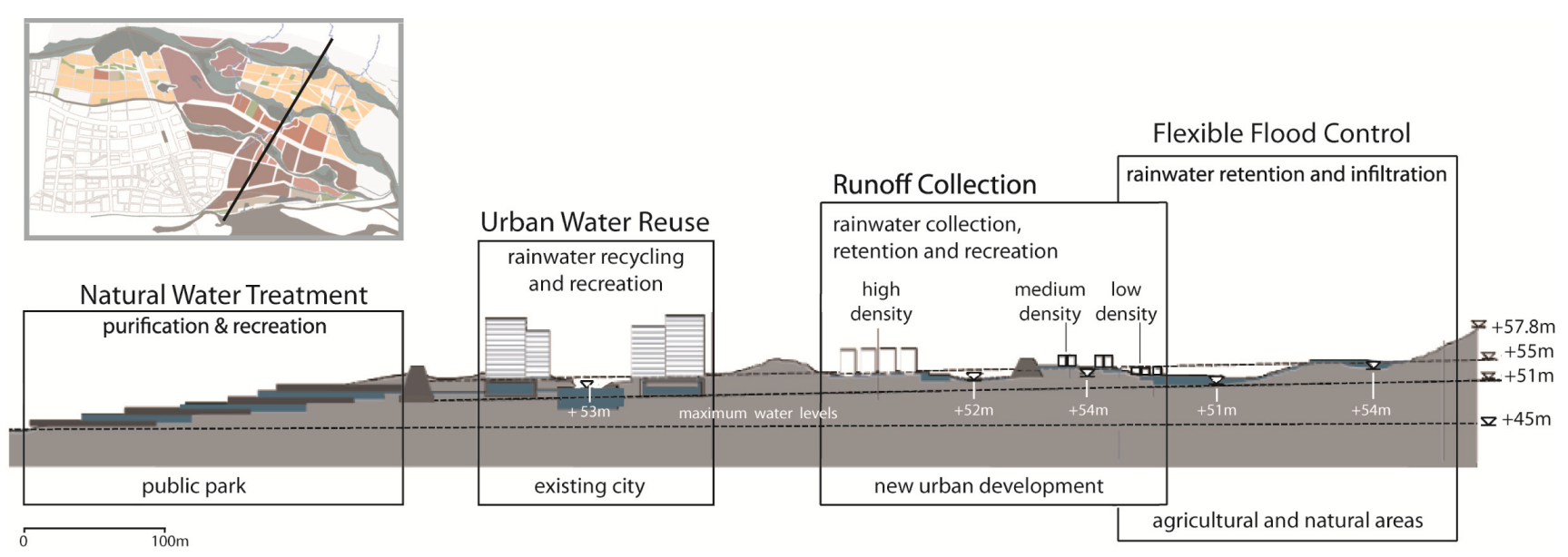

In the general integrated urban development concept, flood-resistant low-density housing is proposed for the areas that are located in the lowlands, south of the northern arm of Dotzpu River, and near the retention lake (see Figures 11 and 12). Medium-density housing is suggested for runoff areas that are located upstream of the lower grounds and discharge filtered stormwater runoff to the retention lake and water storage. It is suggested that the urban development areas with the highest population densities are to be located close to each other in two areas. They should be located both on higher grounds, far from the flood plains above, and on the lower grounds immediately above the hybrid flood plains at the riverside of the southern Dotzpu creek. Here, the surplus runoff water, which could not be retained in the upstream areas, could be collected and utilized for non-drinking purposes. This is useful for reducing the overall water footprint of the urban development, since in areas with higher 
population densities most of the freshwater is consumed per area unit (by private households, as well as public and industrial uses). From this urbanized area, surplus stormwater runoff, which could occur during the wet seasons, could be drained to the last element of the purposed artificial stream structure; it could then finally be treated and discharged to the southern and main stream of the Dotzpu. Here, a hybrid floodplain landscape is proposed along the riverside with the function and characteristic of a public park, where a nature-orientated wetland system is designed and engineered to facilitate both recreational use and the additional purification of stormwater runoff water before it finally enters the main stream and is mixed with Dotzpu River water [31].

Due to the specific characteristics of the catchment and retention areas, with more or less water during the different seasons, this decentralized rain and river management proposal can function as a dynamic and sustainable urban element. It can provide spatial qualities, safety from flooding, seasonal adaptive water management, and environmental education for people living within this dynamic natural and green environment, with water as a leading spatial planning element. Finally, the multifunctional nature-orientated engineered landscape for decentralized water management, with its hybrid floodplains, facilitates many different recreational open-air activities during all seasons.

\section{Final Remarks}

Multifunctional urban landscapes for water management can create synergies and added value by building healthy urban environments with recreational and educational qualities that can protect the urban infrastructure from damage and contribute to sustainable water use and management [38]. Technical and nature-oriented rainwater management systems can be integrated in the spatial planning and design of urban environments that have different characteristics. According to the two case studies presented in the framework of this paper, such rainwater management systems are applicable to temperate climates and lowlands that are situated below sea level, as in the case of East Almere in The Netherlands; and they can also be implemented in urban developments situated in tropical climates and hilly territories, as illustrated in the case of Hsingchu in Taiwan.

Technologies and systems for decentralized rainwater management can be assigned to elements of the urban infrastructure, landscape architecture, and urban ecology, as well as private and public spaces [39]. They can enhance the spatial quality and value of properties, and improve recreational and ecological areas. If such additional values are considered during the planning stage of urban rainwater management systems, they could contribute to the overall sustainability of territories and cities and to the cost efficiency of entire infrastructures. By distributing the construction and management costs to different sectors, the real costs of specific parts or measures of urban rainwater harvesting and management systems could be shared with other sectors such as with the creation and management of urban architecture landscapes and recreational areas. Although initial investment costs for decentralized rainwater management measures could be higher than for conventional stormwater systems, when combined with other projects, the total costs reduce significantly. The economical feasibility of such an integrated approach has been proven by several pilot projects findings $[14,25,26]$.

Through the consideration of multiple functions in the framework of an integrated design process, rainwater management and harvesting systems can contribute significantly to the sustainable development of urban areas and urban water management, based on the concept of integrated water 
resource management [13]. Enhanced resilience, ecology, and livability can be achieved by the reorganization of urban infrastructures, public spaces, and specific water management structures [40]. The technologies and systems, as well as the principles of the proposed conceptual approach, can be adapted to specific natural and structural basic conditions of any other city, particularly in coastal and delta areas (since they suffer similar water-related problems), and in environments with climates that feature precipitation events, temporary flooding, and droughts.

\section{Acknowledgments}

The authors would like to thank Harry de Brauw and Ying-Ching Chen for their contributions to this paper through fruitful discussions and by sharing the results of their research and design work on the case studies of East Almere in The Netherlands and Hsingchu in Taiwan.

This paper was supported by a grant (11 High-tech Urban G04) from the High-Tech Urban Development Program funded by the Ministry of Land, Transport, and Maritime Affairs of the Korean government.

This paper was also supported by the International Science \& Technology Cooperation Program of China (2010DFA74490).

\section{References}

1. McGranahan, G.; Balk, D.; Anderson, B. The rising tide: Assessing the risks of climate change and human settlements in low elevation coastal zones. Environ. Urban. 2007, 19, 17-37.

2. Intergovernmental Panel on Climate Change (IPCC). Climate Change 2007: Synthesis Report; IPCC: Valencia, Spain, 2007; p. 52.

3. Nicholls, R.J. Coastal megacities and climate change. GeoJournal 1995, 37, 369-379.

4. Nicholls, R.J.; Cazenave, A. Sea-level rise and its impact on coastal zones. Science 2010, 328, 1517-1520.

5. De Sherbinin, A.; Schiller, A.; Pulsipher, A. The vulnerability of global cities to climate hazards. Environ. Urban. 2007, 19, 26-39.

6. McDonald, R.I.; Green, P.; Balk, D.; Fekete, B.M.; Revenga, C.; Todd, M.; Montgomery, M. Urban growth, climate change, and freshwater availability. Proc. Natl. Acad. Sci. USA 2011, 108, 6312-6317.

7. United Nations Environment Programme (UNEP). GEO 4 Environment for Development; UNEP: Nairobi, Kenya, 2007; pp. 421-423.

8. Sharma, D.; Tomar, S. Mainstreaming climate change adaptation in Indian cities. Environ. Urban. 2010, 22, 451-465.

9. Fuchs, R.; Conran, M.; Louis, E. Climate change and Asia's coastal urban cities: Can they meet the challenge? Environ. Urban. Asia 2011, 2, 13-28.

10. Adger, W.N.; Arnell, N.W.; Tompkins, E.L. Successful adaptation to climate change across scales. Glob. Environ. Change 2005, 15, 77-86.

11. Tanner, T.; Mitchell, T.; Polack, E.; Guenther, B. Urban Governance for Adaptation: Assessing Climate Change Resilience in Ten Asian Cities; Institute of Development Studies, University of Sussex: Sussex, UK, 2009; Volume 1, p. 47. 
12. McDonnell, R.A. Challenges for integrated water resources management: How do we provide the knowledge to support truly integrated thinking? Int. J. Water Resour. Dev. 2008, 24, 131-143.

13. Schuetze, T.; Tjallingi, S.P.; Correlje, A.; Ryu, M.; Graaf, R.; van der Ven, F. Every Drop Counts: Environmentally Sound Technologies for Urban and Domestic Water Use Efficiency, 1st ed.; United Nations Environment Programme: Nairobi, Kenya, 2008; p. 197.

14. Schuetze, T.; Chelleri, L. Climate adaptive urban planning and design with water in Dutch polders. Water Sci. Technol. 2011, 64, 722-730.

15. Vörösmarty, C.J.; Meybeck, M.; Fekete, B.; Sharma, K.; Green, P.; Syvitski, J.P.M. Anthropogenic sediment retention: Major global impact from registered river impoundments. Glob. Planet. Change 2003, 39, 169-190.

16. Syvitski, J.P.M.; Kettner, A.J.; Overeem, I.; Hutton, E.W.H.; Hannon, M.T.; Brakenridge, G.R.; Day, J.; Vorosmarty, C.; Saito, Y.; Giosan, L.; et al. Sinking deltas due to human activities. Nature Geosci. 2009, 2, 681-686.

17. Wheeler, S.M. Planning for Sustainability: Creating Livable, Equitable and Ecological Communities; Routledge: London, UK, 2004.

18. Berkes, F.; Folke, C. Linking Social and Ecological Systems-Management Practices and Social Mechanisms for Building Resilience; Cambridge University Press: Cambridge, UK, 2000; p. 476.

19. Newman, P.; Beatley, T.; Boyer, H. Resilient Cities: Responding to Peak Oil and Climate Change, 1st ed.; Island Press: Washington, DC, USA, 2009.

20. Van der Vlies, A.; Stoutjesdijk, K.; Waals, H. Effects of Climate Change on Water Management in The Netherlands; Water Environment Foundation: Doordrecht, The Netherlands, 2006; pp. 7213-7232.

21. Schuetze, T. Water and water supply policy in The Netherlands in preparation for climate. In 100th Anniversary of Seoul Waterworks, Seoul International Symposium on Water Policy and Waterworks Technology 2008; Seoul Metropolitean Government: The Korea Chamber of Commerce \& Industry, Seoul, Republic of Korea, 2008; pp. 111-152.

22. Ministry of Transport Public Works and Water Management. A Different Approach to Water, Water Management Policy in the 21st Century; Ministry of Transport Public Works and Water Management: Hague, The Netherlands, 2000; p. 72.

23. Van Stokkom, H.T.C.; Smits, A.J.M.; Leuvenc, R.S.E.W. Flood defense in The Netherlands-A new era, a new approach. Water Int. 2005, 30, 76-87.

24. Tjallingii, S. The water issues in the existing city. In More Urban Water: Design and Management of Dutch Water Cities, 1st ed.; Hooimeyer, F., Vrijthoof, W.T., Eds.; Taylor \& Francis: Leiden, The Netherlands, 2007; p. 240.

25. Hoogheemraadschap Hollands Noorderkwartier. Water in de Stad van de Zon [In Dutch]; Hoogheemraadschap Hollands Noorderkwartier: Purmerend, The Netherlands, 2005.

26. Hoyer, J.; Dickhaut, W.; Kronawitter, J.; Weber, B. Water Sensitive Urban Design Principles and Inspiration for Sustainable Stormwater Management in the City of the Future; Jovis: Berlin, Germany, 2011; p. 115.

27. Brauw, H.D. Duurzam Almere Oost-Ontwerp Van Een Waterhuishoudkundig Systeem [In Dutch]. Master Thesis, Delft University of Technology, Delft, The Netherlands, 31 March 2009. 
28. Schultz, E. Waterbeheersing Van De Nederlandse Droogmakerijen [In Dutch]; TU Delft: Delft, The Netherlands, 1992.

29. Brouwer, R.; van de Giesen, N.C. Inleiding Watermanagment CT3011 [In Dutch]; Lecture Notes; Department Water Management, Delft University of Technology: Delft, The Netherlnds, 2008.

30. KNMI Koninklijk Nederlands Meteorologisch Instituut. Gemiddelde Neerslaghoeveelheid in mm \& Verdamping Volgens Makkink in mm (for Vlissingen, De Kooy, Eelde, De Bilt, Maastricht, Averaged for the Period 1971-2000) [In Dutch]; Koninklijk Nederlands Meteorologisch Instituut: De Bilt, The Netherlands, 2008.

31. Chen, Y.C. Rethinking Taiwan Silicon Valley. Master Thesis, Delft University of Technology, Delft, The Netherlands, 8 September 2008.

32. Lu, H.-Y.; Peng, T.-R.; Liu, T.-K.; Wang, C.-H.; Huang, C.-C. Study of stable isotopes for highly deformed aquifers in the Hsinchu-Miaoli area, Taiwan. Environ. Geol. 2006, 50, 885-898.

33. Lu, H.-H.; Lin, K. Taipei Water Conservation Project Wins Global Award. Available online: http://focustaiwan.tw/ShowNews/WebNews_Detail.aspx?Type=aALL\&ID=201207040036 (accessed on 31 March 2013).

34. Kopinga, J. Site preparation practices in The Netherlands. In Metria 5: Selecting and Preparing Sites for Urban Trees-Fifth Conference of The Metropolitean Tree Improvement Alliance; Kuhns, L.J., Patterson, J.C., Eds.; The Metropolitean Tree Improvement Alliance The Pensylvania State University: Pennsylvania, PA, USA, 1985; pp. 72-84.

35. Wildschut, J.P. Amsterdam. In Great Cities of the World: Their Government, Politics and Planning; Robson, W.A., Ed.; Routledge: Oxon, UK, 1954; pp. 111-139.

36. Schuetze, T. Decentralized Rainwater Management-Solution for sustainable (re)-development and independency. In IWA World Water Conference, Rainwater Harvesting Task Force, Rainwater Harvesting and Management; International Water Association: Beijing, China, 2006.

37. Gnadlinger, J. RWHM for climate change adaptation in the Brazilian semi-arid rural area. In IWA World Water Congress and Exhibition 2008; International Water Association, Rainwater Harvesting Task Force, Rainwater Harvesting and Management: Vienna, Austria, 2008; pp. 1-7.

38. Gunderson, L.H.; Carpenter, S.R.; Folke, C.; Olsson, P.; Peterson, G.D. Water RATs (Resilience, Adaptability, and Transformability) in lake and wetland social-ecological systems. Ecol. Soc. 2006, 11, Article 16.

39. Walker, B.; Holling, C.S.; Carpenter, S.R.; Kinzig, A. Resilience, adaptability and transformability in social-ecological systems. Ecol. Soc. 2004, 9, Article 5.

40. Walker, B.; Salt, D. Resilience Thinking: Sustaining Ecosystems and People in a Changing World; Island Press: Washington, DC, USA, 2006.

(C) 2013 by the authors; licensee MDPI, Basel, Switzerland. This article is an open access article distributed under the terms and conditions of the Creative Commons Attribution license (http://creativecommons.org/licenses/by/3.0/). 